Journal of Social Sciences 3 (3): 134-137, 2007

ISSN 1549-3652

(C) 2007 Science Publications

\title{
Effects of Collateral Pledges in Reducing Credit Risks - Confronting Banks in Jordan, as Lending Institutions
}

\author{
Dr. Ahmad Zakaria Siam \\ Al Balqa Applied University, Amman College for Administrative and Financial Sciences, Jordan
}

\begin{abstract}
The research aims at investigating the effects of Collaterals pledges in reducing credit Risks .To achieve research goals data were collected from all commercial banks operating in Jordan. Research concluded that banks in Jordan use collaterals effectively and in a wide range, and collaterals size have a direct impact on credit risk. Credit risk differs with collaterals.
\end{abstract}

Keywords Collateral, profitability, risks, commercial banks, lending policies

\section{INTRODUCTION}

This study aims at examining the effects of collaterals pledges in reducing credit risks confronting banks in Jordan, and to test the study's hypotheses in this regard. The study consists of dependent variables which represent credit risks confronting banks when granting loans, credit facilities; and independent variables which explain the changes in borrowers' ability to pledge collaterals.

Researcher collected data from different sources such as annual reports of the Jordanian commercial banks, and annual reports issued by the Central Bank of Jordan concerning banks that are in the study's sample and for the peril of the study.

Analytical and descriptive methodology has been used in the study; collected data was analyzed accordingly, interpreted and assessed in order to have an accurate test of the study's hypotheses.

Commercial Banks in Jordan, an Overview: The principle reason banks and many competing lenders are issued charters of incorporation by governments is to make loans to their customers. Banks are expected to support their local communities with an adequate supply of credit for all legitimate business and consumer financial needs and to price that credit reasonably in line with competitively determined market interest rate [3]. Loans support the growth of new businesses and jobs within the lender's trade territory. Despite the benefits of lending for both borrower and institutions, lending is among the riskiest of all banks functions, bank's problems usually spring from loans that have become uncollectible due to mismanagement, illegal manipulation, misguided lending policies or an expected economic downturn. As it happened with Philadelphia Bank in Jordan, which went bankruptcy and acquired by the Ahli Bank. [4]

It is known that Commercial banks are financial institutions which link the borrowers with

banks as lenders. In addition, banks accept deposits: demand deposits, time deposits and saving deposits, etc. Commercial banks in Jordan are governed by the Central Bank of Jordan. The Central Bank operates with favorable policies such as deregulation of interest .Rates and relatively, the reduction of the imposed regulations and restriction on Commercial banks. Consequently, in the last few years new branches in Jordan such as Odeh Bank. There are (8) national banks in 1964, this number increased to (18) bank in 1990 to become (21) bank in 2003 [2].

The number of branches increased from (14) in 1964, Central Bank of Jordan, has taken the fiscal policy practice within the kingdom; it has played an active role by influencing the economic movement in the country (Reylan: 2005) consequently; a positive results have affected the banks. Banks assets increased in 1981 from JD 1330.7 million to JD 3780.3 million in 1989 ad up to JD 14153.6 million in 2001.[2]

The importance of the banking sector in the Jordanian economy can be illustrated by the ratio of banking assets to gross domestic product for the same period to $91.8 \%, 155 \%$ and $223 \%$ respectively .[4]

Jordanian Banks Credit facilities: Commercial banks in Jordan granted up to JD (6003) million by the year 2004 from JD 4348 million in 2000 [2]. Out of this figure, JD 5544 million or $92.4 \%$ of total credit was granted to the private sector, JD 441 million or $7.3 \%$ of 
the total credit went to the public. In addition, that a percentage change of increased items from $62 \%$ in 2000 up to $74 \%$ in 2004 of the total credit facilities. While the percentage change of the bills discounted declined from $28.5 \%$ in 2000 to $5.8 \%$ by the end of 2004 .

This increase in due to the banks credit facilities expansion to include; investment in development project and loans given to housing complexes which is flourishing significantly in and around the Capital Amman, especially its western part. The distribution of credit facilities in the year 2004 is as follows: trade sector $24.1 \%$ of the total credit facilities personal loans and credit cards $26.8 \%$ Industry $16.1 \%$, construction and development $15.78 \%$ and service sector $8.2 \%$ of total granted loans..

\section{MATERIALS AND METHODS}

Research significance: The research significance is stemmed from the importance of the topic the research deals with. In addition to revealing important information about banks performance using collaterals in reducing loan risks in particular and the scarcity of similar studies make this study an important one.

Although banking sector in Jordan is an advanced one in Comparison with banks in third world countries; however, there are many implicit factors which affect the operations of the Jordanian banks lending money in particular. Researcher, through using first hand experience and direct personal knowledge attempted hard to reveal these implicit factors which are: several major banks are owned by wealthy families - The Arab Bank is owned and operated by Shuman family; the National Bank of Jordan (Al Ahli Bank) is owned by Mu'asher family and so forth. Thus relationships and friendships play a great role in granting loons especially to businesses owned by members of these families. Secondly Jordan economy is free market economy; the wealth and the money are restricted to few individuals who are politicians or business people.

- $\quad$ Lost lending money goes to them- an ordinary citizen can't afford to develop vast lands such as The Al Disi Valley, or building. Five star magnificent hotels, rather, very few well established developers use the people's savings to expand and enhance their wealth.

Ordinary citizens use banks mainly to have saving accounts and to mortgage their family house [1].

Thirdly; Banking sector management is the type of "from up down" on the hierarchy management system, CEO is the sole decision maker helped by a mini board of directors consists of relatives or life long associates such as late Abdul Hameed Shuman, Abdul Majeed Shaman and other members of the sons and daughters of the Shuman family. This family run banks affect primarily the ones who want to borrow money.

For instance, selecting the elite to be given (a huge) loan by CEO who knows that the loan will be risk free for one simple reason that is the bank will be a partner of the project or the venture which the loan money will finance it.

Research Hypotheses: The research attempts to test the following results:

Hypothesis No. 1:

Ho:-Borrowers Collaterals pledges have no effect on reducing credit risks.

H1: Borrowers Collaterals pledges have an effect on reducing credit risks

\section{Hypothesis No. 2:}

Ho: There is no correlation between the type of the pledged collaterals and credit risks reduction.

H1: There is a correlation between the type of the pledged collaterals and credit risks reduction

\section{RESULTS AND DISCUSSION}

To find the relation between research variables : Collaterals as independent variable and credit facilities as dependent variable

Bank's size of credit facilities were gathered from all banks annual reports for the period of 2000- 2004, percent changes were computed to give an idea regarding the growth rate of credit facilities. Due to lack of information regarding collateral sizes because of its secrecy, researcher use his own evaluation of effect pledges on credit facilities .Based on the data analysis the research concluded the following results:

- Research revealed that banks in Jordan use collaterals effectively and in a wide range. Collaterals size has a direct impact on credit risk. Banks in Jordan demand higher value collaterals in order to guarantee the pay back of the loan, and not to lose money in case of default.

- Credit risk differs with collaterals. In order to reduce credit risks, a set of reliable and approved collaterals are required. Collaterals are very effective means that force borrowers to fulfill their commitments and obligations to tenders. 
- Nature of credit risk confront the bank varies with the size of the loan and the pledged collaterals. Thus, bank demand greater collaterals as the size of the loan are great too. Sufficient collaterals will reduce the level of potential future default risks.

- Some banks CEO - due to their status in society as being VIP

Mix friendship with business. From researchers experience and his conversation with reliable sources of banks, it has been revealed that some CEO approves loans over the phone for their associates and clans who are important figures in society. As it happened with Philadelphia bank, which went bankruptcy as a result of bad management.

Finally, the results are in a accordance with the results of few previous studies which were conducted by Jordanian researches such as Nimri and Kelani However for researchers best Knowledge that there are no studies conducted by international researchers, However there are sketchy surveys by European Union a bout Jordan's economy in general and Banking system in particular. UN reports about economies of Third world countries including Jordan's are too many.

\section{CONCLUSIONS}

Although Jordanian banks are operating with efficient manner as well as utilizing modern banking methods such as the Arab Bank which is in the process of electronizing all its operations and services; There is still gaps within banks that need to be narrowed or eliminated these gaps or faults come from the bank it self. Either by management - most the time - or by very few fraudulent cases come from some borrowers the rich and famous ones- as it happened with Amjad Shamayleh. Who stole millions of dinar from two banks fraudulently? Thus, management in banks plays a great role in reducing the size of risks.

Therefore, there is a need for specialized sections managed by expert, qualified staff in order to control risk.
Jordanian banks one healthy, they operate profitably. However, they need more of a risk management.

\section{REFERENCES}

1. AL Nimry, Ahmed. 1989, Jordan Banking System and its Participation in the Economic Growth, Development Journal, Vol. 190, March, Amman, Jordan.

2. Central Bank of Jordan, Annual and Monthly. Statistical Bulletin, Research Department, Different Issues, Amman.

3. Rose peter "loans in Trouble in a troubled economy: candian banker No. 3- June 1983.

4. AL Kaliani. Mohammed. 2005. Banking Operations, 1st Edition, Part One, AL Habeeb Press for Publishing and Distribution, Amman, Jordan.

5. Lewis. M. K and Davis .K .T .1987; Domestic and International Banking, Wheaton, Great Britain.

6. Makinen and Gaite. 1981; Money, Banking, and Economic Activity; $5^{\text {th }}$ Edition, Academic Press, N.Y, U.S.A.

7. AL Madaan, Mohammed. 1999. Finance Management in Companies, $2^{\text {na }}$ Edition, $\mathrm{AE}$ Obykat Library, AL- Geria.

8. Hamam, Hytham. 2001. Finance Theory, $1 \mathrm{St}$ Editions, Zarhan Press For Publishing and Distribution, Amman, Jordan.

9. Harvey. J. Modern Economics 1988, Fifth edition, EEBS - Hong Kong Kaufman. G. 1994, Bank Contagion: A Review of the Theory and Evidence, Journal of Financial Services Research 8: 123 - 150.

10. Kenen. B. Peter 1994: The International Economy, Third Edition

11. Aghion, P. and Bolton, P. 1992. An Incomplete Contracts Approach to Financial Contracting '. "Review of Economic Studies", vol. 59,p $473-494$

12. Boot, A .W .A and Thakor, A.V, 2000. Can Relationship Banking Survive Competition? The Journal of Finance, vol. NO.2. April. 679 $-713$.

13. Boot, A .W .A and Thakor, A.V, 2000 . Can Relationship Banking Survive Competition? . The Journal of Finance, vol. NO.2. April. 679 $-713$ 
14. Manove, M and Padilla A.J .2001. 'Collateral Versus Project Screening: A Model of Lazy Banks. RAND Journal of Economics vol. 32,726-744

15. Moyer .R. C, Mcguigan. J, kretlow W, 2001 Contemporary Financial Management, Eight Edition, South, Western College Publishing, Cincinnati, Ohio - U.S.A

16. Turban, E. 2002, "Electronic Commerce a Managerial Perspective", Prentice Hall, U.S.A, p. 179

17. Zairi, A., 2003. "Global Benchmarking for Internet and E-Commerce Applications", Proceedings of the First International Conference on Performance Measure, Benchmarking and Best Practices in New Economy, Business Excellence, May-2003, University of Minho Guimaraes, Portugal

18. Zairi, A and Alwabel, S. 2005. "The Web and it's Impact on the Provision of Financial Services: A Benchmarking Perspective of Saudi Banks" Bradford University School of Management, Working Paper No 05/18, pp. 58

19. Meuter, M., Ostrom, A., Roundtree, R. and Bitner, M, 2000. "Self-Service Technologies: Understanding Customer Satisfaction with Technology-Based Service Encounters", Journal of Marketing, Vol. 64, (July) pp. 5064

20. Moon, Y and Fre, F, 2000. "Exploding the Self-service Myth", Harvard Business Review, 78-3: pp. 26-27
21. Muphy, D. 2000. "Developing Rules to Build online loyalty". Marketing Journal, (June), pp. 31-35

22. Neal, W, 2000. "For Most Customers, Loyalty isn't an Issue", Marketing News, Vol. 34 (April), p. 7

23. Nieto, I, 2001. "Reflection on the regulatory Approach to E-finance", Bank for International Settlements, Information, Press \& Library Services CH-4002 Basel, Switzerland, BIS Papers No. 7

24. Distr, 2003. Development of E-Commerce Sectors in the Arab Region, Proceedings of the Western Asia Preparatory Conference for the World Summit on the Information Society (WSIS), 4-6 February 2003, Beirut

25. Doyle, T. and Melanson, J. 2001 "B2B Web Exchanges: Easier Hyped Than Done", Journal of Business Strategy, 22-3, pp. 10-13

26. Fan, M. 2002. "Electronic Commerce and the Revolution in Financial Markets, Thomson Learning, USA, Pp. 223-238

27. Gronroos, C. 2000. "Service Management and Marketing: A customer Relationship Management Approach, "John Wiley \& Sons Ltd, Chichester, England. Pp. 139-142

28. Hawkins, J, 2001. "The Banking Industry in the Emerging Market Economies: Competition, Consolidation and Systemic Stability: An Overview", BIS Papers No. 4, August, pp. 1-44 